\title{
THE 'OPINIONS OF RELIGION AND DIVINE WORSHIP' IN THE SEVENTEENTH CENTURY POLISH-LITHUANIAN COMMONWEALTH FROM AN ENGLISH AND SCOTTISH PERSPECTIVE
}

\begin{abstract}
The article analyses English and Scottish travellers' accounts of interdenominational relations, and specifically religious toleration, as observed in the seventeenth century Polish Lithuanian Commonwealth. It traces the changing British perception of these matters over time, from when toleration was a subject of admiration until it began to be seen as a sign of anarchic religious liberty, a weakness; something to be, as Gilbert instigated, 'abolished and removed from the body and the bounds' of the English monarchy.
\end{abstract}

Key words: Poland-Lithuania; English and Scottish travel accounts; religious toleration

Słowa kluczowe: Rzeczpospolita; Angielskie i szkockie relacje podróżnicze; tolerancja religijna

Seventeenth century English and Scottish travellers' accounts of their visits to the Polish Lithuanian Commonwealth (PLC) and the Est Partis were preoccupied with descriptions of its lands, people and customs, and/or the political, economic and religious situation; they concentrated primarily on recording the curiosities, and thus the differences, between the two parts of Europe. ${ }^{1}$ One of the more polarising issues between the inhabitants of Poland-Lithuania and visitors from the British Isles was, as Scottish traveller and

\footnotetext{
1 The term 'Est Partis' appearing in the $16^{\text {th }}$ and $17^{\text {th }}$ century Scottish documents, e.g. an inventory of the birth briefs from Aberdeen, was used to describe territories east of the Polish Lithuanian Commonwealth, usually Muscovy. See 'Testimonial Issued in the City of Aberdeen on 18 July 1590', The Miscellany of the Third Spalding Club [hereafter MTSC] (Aberdeen: 1940), vol. 2, no. 3.
} 
celebrated satirical writer John Barclay (1582-1621) described, 'opinions of Religion, and heauenly matters.' The commonly exaggerated accounts of Poland-Lithuania - 'a Nation borne to cruelty and licentiousnesse'- evoke an image of an exotic, distant and isolated part of Europe. ${ }^{3}$ Yet this was not necessarily the perception of contemporary Commonwealth inhabitants. During the last decades of the sixteenth century and the first half of the seventeenth century, when English interests took a definitive turn towards England's new colonies and especially opportunities on the other side of the Atlantic, both states established much closer contacts than possibly any other previous period in history. Political, economic and cultural exchanges, which were heavily influenced by English and Scottish trade as well as English economic interests in this part of Europe - such as the formation of the Eastland Company in 1579, or migration from Scotland between the 1590 s and 1650 s - also involved more personal connections. ${ }^{4}$ Of particular significance is immigration. At approximately this time, a considerable group of Scots, and some English, migrated to Poland-Lithuania, in the process forming several larger communities. The region witnessed an influx of an array of different traders, soldiers, students, theologians, academics and intrepid travellers who, in the tradition of the Grand Tours, ventured into 'Polonia and the Provinces thereof'. At its peak, by the 1640s, the Scottish diaspora in Poland-Lithuania may have consisted of several thousand individuals. While

2 John Barclay, Ioannis Barclaii Icon animorum, Londini: Ex officina Nortoniana apud Iohanne Billium, M.DC.XIV. [1614], 187.

3 Ibid., 186.

4 The most definitive text on the subject is the monograph by Edward Alfred Mierzwa, Anglia a Polska $w$ XVII wieku [England and Poland in the Seventeenth Century] (Toruń: Wydawnictwo Adam Marszałek, 2003); idem, Anglia a Polska w pierwszej potowie XVII w. [England and Poland in the First Half of Seventeenth Century] (Warszawa: Państwowe Wydawnictwo Naukowe, 1986); idem, Anglia a Polska w epoce Jana III Sobieskiego [England and Poland during the John III Sobiecki era] (Eódź: Wydawnictwo Eódzkie, 1988). His most recent publication, Anglia a Polska w XVII wieku, presents a broad survey of political, economic and cultural contacts between Poland-Lithuania and England, and the role that England's trade and economic interests played in shaping these relations. Importantly, this is the first text in Polish historiography that thoroughly examines the 50 volumes of the 'Calendar of State Papers from 1574-1685', published in London in 1702-1939. Cf. Zdzisław Taźbierski, 'Związki Polski z Anglią od schyłku XIV do polowy XVII wieku' [Poland's Interelation with England from the End of the Fourteenth to the mid-Seventeenth Century], Studium z dziejów polityki dynastycznej (Olsztyn: Wyższa Szkoła Pedagogiczna, 1994), 25-120; Henryk Zins, Polska w oczach Anglików XIV-XVI wieku [Poland from the English Perspective from the Fourteenth to Sixteenth Centuries] (Warszawa: Państwowy Instytut Wydawniczy, 1974). Close connections between the Polish Protestants and England have been discussed by Nicholas Hans, 'Polish Protestants and Their Connections with England and Holland in the $17^{\text {th }}$ and $18^{\text {th }}$ Centuries', The Slavonic and Eastern European Review, XXXVII (1958/1959), 196-220.

5 Agnieszka White, Obraz kultury Rzeczypospolitej w angielskich relacjach podróżniczych: (koniec XVI i XVII wieku) [The Depiction of the Culture of the Polish-Lithuanian Commonwealth in English Travel Accounts Towards the End of the Sixteenth- and During the Seventeenth-Century] (Warszawa: Wydział Polonistyki Uniwersytetu Warszawskiego, 2014); David Worthington, British and Irish Experiences and Impressions of Central Europe, 1560-1688 (Aldershot: Ashgate, 2012); Cf. John Stoye, English Travelers 
many stayed temporarily (having generated enough income, some Scots returned home), others settled permanently and exercised commercial business and crafts. Their decision to migrate was heavily influenced by the economic opportunities then available in the Commonwealth but also, although to a lesser degree, by the state's tolerance of different creeds and its distinct multi-ethnic character. The migration slowed significantly only after the Swedish Deluge (1655-1660), before coming to a halt in the first decades of the following century. ${ }^{6}$

The fall in the number of migrants - as reflected, for instance, by the substantial 50 -60 per cent or above decrease of Scottish names appearing in the vital records and lists of communicants of all Polish Protestant parishes between the early 1650 s and 1660s - was symptomatic of Poland-Lithuania's economic decline and its attitude towards nonconformists. ${ }^{7}$ Several accounts have been published of the conflicts between local Protestants, who the immigrants overwhelmingly joined, and those 'addicted to the Roman See'. Other writings concerning the religious developments in Poland-Lithuania also reached Britain. Examples of these will be examined to see how they may have influenced the way the Polish-Lithuanian Commonwealth was perceived and gradually estranged in the minds of the general public, not only in the British Isles but also in other parts of Western Europe.

It appears that the developments of Protestant thought in the Commonwealth, including the Antitrinitarian ideology, had been acknowledged in the British Isles since the 1550s. The Polish brand of Protestantism was first introduced there by Jan Easki, better known in England as John a Lasco (1499-1560). After being expelled from his post of

Abroad, 1604-1667 (Yale: Yale University Press, 1989); Edward Chaney and Timothy Wilks, The Jacobean Grand Tour: Early Stuart Travellers in Europe (London: I. B. Tauris, 2014).

${ }_{6}$ This migration has been a subject of a number of recent publications. The most comprehensive texts in English on the subject include: Peter Paul Bajer, Scots in the Polish-Lithuanian Commonwealth in the Sixteenth to the Eighteenth Centuries: The Formation and Disappearance of an Ethnic Group (Leiden: Brill, 2012); Waldemar Kowalski, The Great Immigration: Scots in Cracow and Little Poland, circa 1500-1660 (Leiden: Brill, 2015); Michael Broun Ayre, The Scottish Community in the Grand Duchy of Lithuania, 1630-1750 (Kaunas: Humanitas, 2020); Cf. Anna Biegańska, 'A Note on the Scots in Poland, 1550-1800', ed. Thomas Christopher Smout, Scotland and the Sea (Edinburgh: John Donald Publishers, 1992); idem, 'In Search of Tolerance: Scottish Catholics and Presbyterians in Poland', Scottish Slavonic Review, XVII (Autumn 1991), 37-59; Waldemar Kowalski, 'The Placement of Urbanised Scots in the Polish Crown During the Sixteenth and Seventeenth Centuries', Scottish Communities Abroad In The Early Modern Peri$o d$, eds. Alexia Grosjean, Steve Murdoch (Leiden: Brill, 2005); idem, 'The Reasons for the Immigration of Scots to the Polish Commonwealth in the Early Modern Period as Outlined in Contemporary Opinions and Historiography', Paper presented to the Scotland and Poland: a Historical Relationship, 1500-2009 Conference, School of History, Classics and Archaeology (Edinburgh: The University of Edinburgh, October 1-2, 2009).

7 Detailed analysis of records of major Reformed parishes of the Polish-Lithuanian Commonwealth, carried out in order to estimate the number of immigrants, has been presented in: Bajer, Scots in the Polish-Lithuanian Commonwealth, op.cit., 235-301. 
superintendent of all East Friesian churches, he was invited to England by Archbishop Thomas Cranmer. Easki was asked to participate in a doctrinal colloquy summoned by Cranmer as part of his programme of religious reform. In 1550, the Archbishop appointed him superintendent of the Dutch Strangers' Church in London, which served as a place of worship for Protestant refugees mainly from the Low Countries and France. It has been suggested that the ceremonies used by £aski's congregation, described in his most famous work Forma ac ratio (1555), may have had some influence upon The Book of Common Prayer (1552), especially on penitential rites. More direct lines of influence have been traced to John Knox's Scottish order (1560-61) and to the Middleburg ordinal (1602), later used by English Puritans. ${ }^{8}$

The interest in Protestant religious doctrines developed in Poland-Lithuania increased in England during the first half of the seventeenth century. This curiosity was fuelled by a reaction against the revival of Catholicism during the Stuart era, as well as growing divisions between King James VI (I) (1566-1625), a firm supporter of the High Anglican Church, and the Puritans who controlled Parliament. The Polish Antitrinitarians, otherwise known as the Polish Brethren (Bracia Polscy), judged this situation to be a perfect opportunity to present their own beliefs to the monarch and to the wider English audience. In 1609, Hieronim Moskorzewski dedicated the Latin translation of Katechizm Rakowski (first published in 1605) to King James. ${ }^{9}$ It appears that the Unitarians completely misread James' intentions. The king took such offence at the radical views presented in the publication that he ordered all copies of it to be confiscated and burnt. According to Teslar, however, the monarch's swift attempt to stop the publication was not embraced

8 Łaski's undertakings in England have been discussed in: Oskar Bartel, Jan Easki (Warszawa: Neriton, 1999); Basil Hall, John à Lasco 1499-1560: A Pole in Reformation England (London: Dr Williams Trust, 1971); Dirk Wayne Rodgers, John à Lasco in England (New York-Washington: Peter Lang, 1994). The subject of the reformer's activity after returning to Poland has been best described in: Halina Kowalska, Dziatalność reformatorska Jana Easkiego w Polsce 1556-1560 [Jan Łaski's Reform Activities in Poland 1556-1560] (Warszawa: Neriton, 1999). Cf. Dirk Wayne Rodgers, 'Á Lasco [Laski], John (1499-1560)', Oxford Dictionary of National Biography (Oxford: Oxford University Press, 2004), [http://www.oxforddnb.com/view/article/16081, accessed 10 April 2010]; Michael S. Springer, 'Johannes a Lasco, a Polish and European reformer', A Companion to the Reformation in Central Europe, eds. Howard Louthan and Graeme Murdock (Leiden: Brill Publishing, 2015), 161-168; idem, Restoring Christ's Church: John a Lasco and the Forma ac ratio (Aldershot: Ashgate, 2007), 198; Henning P. Jürgens, Jan Łaski 1499-1560. Europejczyk doby reformacji [Jan Łaski 1499-1560. European of the Reformation Era] (Warszawa: Semper, 2006).

9 Catechesis Ecclesiarum quae in Regno Poloniae et magna Ducatu Lithuaniae, et aliis ad istud Regnum pertinentibus Provinciis, affirmant, neminem alium, praeter Patrem Domini nostri Jesu Christi, esse illum unum Deum Israëlis: Hominem autem illum Jesum Nazarenum, qui ex Virginenatus est, nec alium, praeter aut ante ipsum, Dei Filium unigenitum, et agnoscunt et confitentur. Ante annos quatuor Polinicè, nunc verò etiam Latinè edita (Racoviæ, 1609); Cf. Beata Cieszyńska, 'Literackie okruchy religijnych peregrynacji Brytyjczyków w Polsce (do początków XVIII wieku)', Napis, 11 (2005), 81-96. 
by a Parliament hostile to him. ${ }^{10}$ A lack of action over the following years allowed for the book's wide publication and a number of reprints and later translations. ${ }^{11}$ When in 1652 Parliament finally passed a resolution commanding the "Blasphemous, Erronious and Scandalous' [sic] catechism to be seized and burnt at the Old Exchange in London, it was all too late. ${ }^{12}$ The attempt to suppress the book was unsuccessful, and merely sparked new endeavours to make it available. ${ }^{13}$ This and other works had a considerable influence on the philosophical and theological ideas of John Locke (1632-1704) and Sir Isaac Newton (1643-1727). Newton in particular had a considerable interest in the ideas of the Polish Antitrinitarians. It has been noted that in his private collection, Newton had eight

10 Józef Andrzej Teslar, 'Polskie wydawnictwa ariańskie w bibliotekach angielskich', Rocznik Polskiego Towarzystwa Naukowego na Obczyźnie, IX (1958-69), 46.

11 Catechesis ecclesiarum quae in regno Poloniae \& magno ducatu Lithuaniae, \& aliis ad istud regnum pertinentibus provinciis, affirmant, neminem alium praeter patrem Domini nostri Iesu Christi, esse illum unim Deum Israëlis: hominem autem illum Iesum Nazarenum, qui ex virgine natus est, nec alium, praeter aut ante ipsum, Dei filium unigenitum \& agnoscunt \& confitentur. Cui accedit Fausti Socini Senensis vita. Et dissertatio operibus suis ab Equite Polono praemissa. Cum catalogo operum ejusdem Fausti Socini. Dissertatio quam Fausti Socini operibus praemitti voluit. Dissertatio quam Fausti Socini operibus praemitti voluit., Racoviae [i.e. London: Printed by William Dugard], anno Domini M.DC.LI. [1651]. The Racovian catechisme voherein you have the substance of the confession of those churches, which in the kingdom of Poland, and great dukedome of Lithuania, and other provinces appertaining to that kingdom, do affirm, that no other save the Father of our Lord Jesus Christ, is that one God of Israel, and that the man Jesus of Nazareth, who was born of the Virgin, and no other besides, or before him, is the onely begotten Sonne of God. [Apparently translated from the Latin version], (Printed at Amsterledam [sic]: for Brooer Janz, 1652).

12 Cf. Votes of Parliament touching the Book commonly called The Racovian Catechisme (London: printed by John Field, Printer to the Parliament of England, 1652).

13 Apart from the catechism several works of an influential Socian theologian S. Przypkowski have been translated into English. His Dissertatio de pace has been translated and published in London in 1653, 1684 and 1688. Przypkowski prepared also a volume dedicated to the life and work of Faustus Socinus. Cf. S. Przypkowski, Dissertatio de pace, \&c. Or, A discourse touching the peace \& concord of the Church. Wherein is elegantly and acutely argued, that not so much a bad opinion, as a bad life, excludes a Christian out of the kingdom of heaven; and that the things necessary to be known for the attainment of salvation, are very few and easie: and finally, that those, who pass amongst us under the name of hereticks, are notwithstanding to be tolerated (London: printed by Ja: Cottrel, for Rich. Moone, at the seven stars in Paul's Church-yard., 1653); idem, Dissertatio de pace, \& c. Or, A discourse touching the peace and concord of the Church. Wherein is elegantly and acutely argued, that not so much a bad opinion, as a bad life, excludes a Christian out of the kingdom of heaven: and that the things necessary to be known for the attainment of salvation, are very few and easie: and finally, that those, who pass amongst us under the name of hereticks, are notwithstanding to be tollerated (London: printed [by J.G. from Thomas Malthus], 1684); idem, Dissertio de pace, Scc, or, A discourse touching the peace and concord of the Church wherein First, is elegantly and accurately argued, that its not so much a bare error in opinion ... secondly, that the things necessary ... Lastly, that those who pass amongst us... (London: printed and sold by Andrew Sowle ..., 1688); idem, The life of that incomparable man, Faustus Socinus Senensis, described by a Polonian knight. Whereunto is added an excellent discourse, which the same author would have had premised to the works of Socinus; together with a catalogue of those works (London: printed for Richard Moone, at the seven Stars in Pauls Church-yard, neer the great north-doore, 1653). 
of their books, and that he most likely accessed the anthology of Unitarian writing, the famous Bibliotheca Fratrum Polonorum. ${ }^{14}$

It appears that the eventual banishment of the Polish Brethren from Poland in 1658 (members of the Brethren were given two years to embrace Catholicism and stay, or sell their belongings and go into exile), did not cause much controversy in the British Isles. When it came to Arianism, both Poland-Lithuania and England, despite dissimilar views on religion, showed a comparable disapprobation towards this particular theology. An article from Moderate Intelligencer about the exclusion of the sect from the Colloquium Charitativum (English: Brotherly Conversation) conference organised by Władysław IV in Toruñ on 28 August 1645, which aimed to bring agreement between Catholics, Calvinists, and Lutherans of Poland, perfectly illustrates this situation. Apart from making a note of the episode, the author of the commentary has actually validated the position of the King of Poland in not inviting the Arians. Their doctrine, reported the correspondent, was 'most to be feared of all others that have, since the redemption of mankind, infected the Church'. ${ }^{15}$

This was neither the first nor the last account in England of the religious developments in the Polish-Lithuanian Commonwealth. In 1645, for example, a royal edict of Władysław IV, King of Poland, directed at the religious dissidents among his subjects, was published in London. ${ }^{16}$

14 Zenon Gołaszewski, Bracia polscy (Toruń: Wydawnictwo Adam Marszałek, 2005), 295, 306, 310, 311 -312, 317-318; Stephen D. Snobelen, 'Isaac Newton, Heretic: the Strategies of a Nicodemite', British Journal for the History of Science, 32 (1999), 384-387; Richard S. Westfall, 'Newton, Sir Isaac (1642-1727)', Oxford Dictionary of National Biography (Oxford: Oxford University Press, 2004); online edn, Jan 2009 [http://www.oxforddnb.com/ view/article/20059, accessed 22 May 2010]; John R. Milton, 'Locke, John (1632-1704)', Oxford Dictionary of National Biography (Oxford: Oxford University Press, 2004); online edn, May 2008 [http://www.oxforddnb.com/ view/article/16885, accessed 22 May 2010]; Cf. George Huntston Williams, The Polish Brethren: Documentation of the History and Thought of Unitarianism in the Polish-Lithuanian Commonwealth and in the Diaspora 1601-1685 (Missoula, Mont.: Scholars' Press, 1980); Wojciech Kriegseisen, Between State and Church: Confessional Relations from Reformation to Enlightenment: Poland - Lithuania - Germany - Netherlands (Bern: Peter Lang Edition, 2016), 318-578.

15 The author of the article mistakenly reported that the Arians were expelled from Poland, when in fact, at this stage, they were simply refused the opportunity to partake in the conference. Among the guests there were 26 Catholic, 28 Lutheran and 24 Calvinist theologians. Among those who attended were notable men such as the Moravian educator Jan Ámos Komenský and the Lutheran theologian Georg Calixt. The conference ended up in disappointment. Rather than discuss reconciliation, a number of the delegates engaged in doctrinal disputes. Although the negotiations continued until $24^{\text {th }}$ November, no progress was achieved. 'The banishment of Arianism out of Polonia: with the entertainment of a Polonian Embassador in Muscovia', Moderate Intelligencer (Thursday, June 17, 1645), Issue 119, 1134-1135. Cf. Edmund Piszcz, Colloquium Charitativum w Toruniu A.D. 1645: geneza i przebieg (Toruń: Wydawnictwo Konserwatora Diecezjalnego, 1995).

16 Universalium sacrae regiae majestatis Poloniae \& Sueciae, \& co ad dissidentes ab Ecclesia Catholica Romana: et literarum illustrissimi ac Reverendissimi Dn. Archiepiscopi Gnesnensis regni primatis, \&c. ad eosdem: tum ad universales S.R. majestatis deputorum ab eclesiis regni \& M.D. Lithuan. evangelicis Orlae congregatorum, supplicis libelli. Ac eorundem ad literas illustrissimi \&c. Dn. Archiepiscopi responsionis, ex originalibus 
Issues of faith were also the subject of a considerable part of an official report commissioned for Queen Elizabeth I or King James VI (I) in the 1590s. Although A Relation of the State of Polonia and the united Provinces of that Crown, Anno 1598 did not reach either monarch, it nevertheless arrived in London in 1604 and must have been known to some of the Court officials. ${ }^{17}$ While in geographical terms Poland-Lithuania was perceived to be, as the report referred to it, 'the most Easterly region of Europe', in the religious sense it was described as very much a part of Western Christendom, 'the Latyn Church.' ${ }^{18}$ Despite the fact that the report never reached a wider audience, the views presented therein appear to be symptomatic of the way many inhabitants of the British Isles envisaged the religious situation in Poland-Lithuania in the 1580s and 1590s, and in the first four decades of the seventeenth century.

Religion in thys lande is manifold, bothe for manyfest opposition and diversity of sectes which commes, for that it confynes with nations of most contrary rites, all men drawing by nature some novelty from theire neighboures. And therfore borderers uppon severall religions doe never syncerely observe that of theire contrey, but mixe it with borrowed superstitons. [...] besydes the wonderfull nombers of heretikes, especially in the capitall article of the Trinity, there are many Qui aut nullos, aut Deos tantum colunt impios, the collission of dyvers opinions easely corrupting, if not altogeather extinguishing the religious affection of mans mynde. [There are also those who follow] Turcisme, Mahumet, and Judaisme,... ${ }^{19}$

fidelis transcriptio. Feb. 15. 1644. Imprimatur. Ja. Cranford. (Londini: Excudebat E.G. impensis Johannis Rothwell, sub signo Solis in Coemeterio Paulino, 1645).

17 'A Relation of the State of Polonia and the united Provinces of that Crown, Anno 1598', Elementa ad fontium editiones, vol. XIII: Res polonicae ex archivio Musaei Britannici Pars 1 [hereafter EFE], edited by Carolus H. Talbot (Roma: Institutum Historicum Polonicum Romae, 1965). The authorship of this document remains unresolved. Originally it was attributed by the archivists G. Warner and J. Gilson to Sir George Carew (c.1556-1612), an English diplomat and historian who visited Poland in 1598. A number of Polish historians have expressed a view that Carew was far too young and his stay in Poland was too short to fully comprehend all events described in this report. The scholars concluded that intricate knowledge of the events suggests that the report must have been written by an insider, someone who spent several years in Poland-Lithuania and most probably within the circle of the Court or its top officials. In 1937 Stanisław Kot proposed that the authorship of the report could be attributed to the Scot William Bruce (Brucius) who not only took part in the Commonwealth's military campaigns, but also was closely connected to the inner circle i.e. Chancellor Jan Zamoyski. Kot's theory of Bruce's authorship of the report, however, has been, in turn, recently disputed by Sebastian Sobecki. Sobecki argued that for a number of reasons this hypothesis is ill-founded and the issue of authorship requires further study. Cf. Stanisław Kot, 'Bruce William', Polski Stownik Biograficzny [hereafter PSB], vol. 3, 3-4 (Warszawa: Ossolineum, 1937); Edward Mierzwa, 'Angielska relacja o Polsce z roku 1598', Annales UMCS, 17 (1962), 88-96; idem, Anglia a Polska, op. cit., 166-167; Sebastian Sobecki, 'The Authorship of A Relation of the State of Polonia, 1598, The Seventeenth Century, 18, no. 2 (2003), 172-179.

18 'A Relation of the State of Polonia', op. cit., 4, 64-67.

19 Ibid., 64-67. 
The 'Papists', as noted later, may have been the most numerous and the most privileged amongst the other creeds, but, according to the report's author, members of smaller denominations did not need to fear persecution. The Constitution of 1573, proclaiming religious tolerance, encompassed not just the two or three most prevalent Religious groups strong enough to fight for their rights in an open-armed conflict. While other, smaller groups were being prosecuted in some Western countries, this Constitution proclaimed tolerance to all creeds. These 'articles of publice peace', as the Relation called it, secured a unity of the state inhabited for generations by diverse ethnic and religious communities. For obvious reasons, the report concentrated on the situation of the non-conformists.

The Christians are subdevided into the Latyne and orientall Churche. Thys latter into the Greek and the Armenian. The Latyn into suche as have publike churches and those which eyther communicate in Conventicles, or privately mainteyn, and propagate theire opinions. Those which have publike churches are the Papistes, Calvinistes and Lutheranes. [...] Of Protestants the Calvinistes in Polonia are in greatest nomber, In Prussia and Livonia the Lutheranes [...] In theise contreys are also greate stoare of Anabaptistes, Osiandristes [PPB: followers of Andreas Osiander, German humanist, reformer, and theologian, who differed with Luther's teaching on the question of the relationship between justification and sanctification, the church discipline and private confession], Ebionites (sic), and of all sortes of Antitrinitaries. ${ }^{20}$

English historian and cartographer John Speed (1551/2-1629) published a very similar account in 1631 . While his description of religious matters was not as detailed as that presented in the 1598 Relation, it reached a much larger audience. ${ }^{21}$

20 Ibid., fol. 42v-43. See also Edward Rosen, 'Osiander, Andreas', Dictionary of Scientific Biography, ed. Charles Coulston (New York: Charles Scribner's Sons, 1974), vol. 10, 245-246.

21 "They haue a good minde to Religion, but cannot fasten vpon one to their liking; and therefore they will try all Christians, they haue beene euer since the yeare 965 , but from that time, they haue scarce any slipt any error, schisme, or heresie, which hath crept into the Church. Here are Iesuites, and other of Romish sects. Here are Lutherans and Calvinists, and Arians, and Anabaptists, and Antitrinitarians: none allowed, but tollerated: and indeed Poland had the senioritie of Amsterdame for that old saying: that if a man had lost his Religion, here he might finde it. They haue one ancient custome in their Churches which me thinkes may well interpret our standing vp at rehershall of the Creed: whe the Gospell is reading, the Nobilitie \& Gentry vnsheath their swords, and stands as it were prepared to defend it with their liues against any which dare violate it." - J. Speed, A prospect of the most famous parts of the vvorld Viz. Asia, 3 Affrica, 5 Europe, 7 America. 9 VVith these kingdomes therein contained, Grecia, 11 Roman Empire, 13 Germanie, 15 Bohemia, 17 France, 19 Belgia, 21 Spaine, 23 Italie, 25 Hungarie, 27 Denmarke, 29 Poland, 31 Persia, 33 Turkish Empire, 35 Kingdo: of China, 37 Tartaria, 39 Sommer Ilands, 41 Ciuill Warres, in England, Wales, and Ireland. You shall finde placed in the beginning of the second booke marked with these [3 asterisks in triangle formation] and (5) Together with all the prouinces, counties, and shires, contained in that large theator of Great Brittaines empire. Performed by Iohn Speed (London: printed by Iohn Dawson for George Humble, and are to be sold at his shop in Popes-head Pallace, 1631), 32. Cf. Sarah Bendall, 'Speed, John (1551/2-1629)', Oxford Dictionary of National Biography (Oxford: Oxford University Press, Sept 2004); online edn, Jan 2008 [http://www.oxforddnb.com/view/article/26093, accessed 16 May 2010]. 
The observations described in the 1598 Relation as well as Speed's account reappeared in several other reports of visits to the Commonwealth. Worthy of note is a lesser known account left by Eleazar Gilbert, a Scottish minister sent in 1638 to Kedainiai (Polish: Kieydany), a private city of the Duke Radziwi ${ }^{33}$ family and an important Calvinist centre, to look after the Scottish and English Reformed congregation residing there. Gilbert noted in his book Nevves from Poland that Vilnius (Polish: Wilno) was a town 'little inferior to the Citty of London' and '.... Citty [of] sumptous Churches, faire buildings, multitude of people, frequency of commerce, and in a word, aboundance of all good things.22 Preceding giving a detailed report of an assault on the local Reformed church, Gilbert favourably assessed the overall religious situation in the city.

There be also therein many Religions professed and tolerated, where-unto also belong many Churches and places of Divine worship, as a Synagogue to the Jewes, whereof there be many thousands in that Citty; a Ruthenian Church to the Russians, a Mahumetan Church to the Tartarians; a Church to the Lutherans; all which doe enjoy their exercises of Religion without trouble or interruption. ${ }^{23}$

An analogous description of Vilnius appeared in 1648 in a London based newspaper:

There is no place in the world wherein God is prayed unto in more fashions then in this Towne; for besides that there be in it great store of goodly Catholike Churches, well served, the Graecians United with the Church of Rome, have likewise many fair ones within it; as likewise the Schismaticall Graecians, The Calvinists, Lutherans, and Arminians have there their severall Temples; the Jews their Synagogues; and the Turks their Mosquees. ${ }^{24}$

This state of affairs had not gone unnoticed by John Durie (1596-1680), the eminent Scottish preacher and ecumenist, who between 1627 and 1630 ministered to the English and Scottish Calvinists in Elbląg. While the influences of David Pareus and William Forbes, recognized for their campaigns of ecclesiastical reconciliation and search for religious tolerance, likely played a considerable role in the formulation of Durie's irenic doctrine, it has been argued that Durie's experience in Poland was equally significant. Biegañska suggested that the well-published Durie several times in his correspondence emphasized

22 Eleazar Gilbert, Nevves from Poland wherein is declared the cruell practice of the popish clergie against the Protestants, and in particular against the ministers of the city of Vilna, in the great dukedome of Lithuania, under the governement of the most illustrious prince, Duke Radziwell / faithfully set downe by Eleazar Gilbert... (London: by E.P. for Nathanael Butter, and are to be sold at his shop, 1641), 6. Cf. Ayre, The Scottish Community, op. cit., 51-99, 293-294.

23 Gilbert, Nevves from Poland, op. cit., 7.

24 Moderate Intelligencer (London, Thursday, April 20, 1648), Issue 162, 1282. 
the favourable positions of the dissenters in Poland-Lithuania, and praised the state's tolerance and security. According to Durie, such auspicious circumstances enabled the non-conformists to enjoy a relatively peaceful coexistence with followers of other creeds and maintain a dialogue with members of other Protestant denominations. ${ }^{25}$

The rise in the migration of Scots and, to a lesser degree, Englishmen to Poland-Lithuania during the last decades of the sixteenth century and the first half of the seventeenth century seems to indicate that a large section of contemporary English and Scottish society was well aware of the religious tolerance in the Commonwealth. While decisions to migrate were fundamentally influenced by the considerable economic opportunities available in the Commonwealth at that time, the state-guaranteed tolerance of diverse faiths and its distinct multi-ethnic character could have likewise appealed to some prospective immigrants. Poland-Lithuania may have specifically attracted individuals whose opportunities for employment or a career progression might have been closed off in Britain because of their religious beliefs, or who were religious refugees. ${ }^{26}$ The considerable denominational violence and persecution in Scotland forced, for example, young Scottish Catholics to continue their education at the Jesuit seminary and college in Braunsberg (today Braniewo). Although it is impossible to assess how many Scots were actually enrolled in the college, as its records no longer exist, the example of its pupil, Patrick Gordon, indicates that around the 1650 s some of his compatriots were certainly enrolled there. ${ }^{27}$ More is known about the Papal Seminary which was established in 1575 with the idea of preparing the men from countries engulfed by Protestantism for priesthood. Between 1580 and 1659, around 45 novices from Scotland were recorded. ${ }^{28}$

25 Anna Biegańska, 'In Search of Tolerance: Scottish Catholics and Presbyterians in Poland', Scottish Slavonic Review, 17 (1991), 37; Steve Murdoch, Network North: Scottish Kin, Commercial and Covert Associations in Northern Europe 1603-1746 (Leiden: Brill, 2006), 281-282; Cf. John T. Young, 'Durie , John (1596-1680)', Oxford Dictionary of National Biograph (Oxford: Oxford University Press, Sept 2004); online edn, Jan 2008 [http://www.oxforddnb.com/view/article/8323, accessed 15 May 2010].

26 The economic reasons as the primary cause for the emigration were identified by both British and Polish historians. Anna Biegańska, 'Żołnierze szkoccy w dawnej Rzeczpospolitej', Studia i Materiaty do Historii Wojsk, no. 27 (1984), 85; eadem, 'In Search of Tolerance', op. cit., 37; eadem, 'The Learned Scots in Poland: From the Mid-Sixteenth to the Close of the Eighteenth Century', Canadian Slavonic Papers, 43 (2001), 2; Michael Flinn et al., Scottish Population History from the 17th Century to the 1930s (Cambridge: Cambridge University Press, 1977), 7-8; Alex J. S. Gibson, Thomas Christopher Smout, Prices, Food and Wages in Scotland 1550-1780 (Cambridge: Cambridge University Press, 1995), 12 and passim. Cf. Kowalski, 'The Reasons for the Immigration', op. cit., 12.

27 'Braniewo', Encyklopedia wiedzy o Jezuitach na ziemiach Polski i Litwy 1564-1995, ed. Ludwik Grzebień (Kraków: Wydawnictwo WAM, 1996), 63-66. In his diary Gordon specifically mentions that his enrolment at the college was pre-planned, suggesting an undescribed link to that school. Among possible students of the college was for example his countryman Thomas Menzies with whom Gordon travelled to Braniewo. Gordon, 'Diary 1659-1667', RSAMH, Fond 846, op. 15, vol. 1, fol. 4-5.

28 Die Matrikel des päpstlichen Seminars zu Braunsberg 1578-1798, ed. Georg Lühr (Braunsberg und Ermländische Verlagsgesellschaft, 1925); Uczniowie - Sodalisi gimnazjum jezuitów w Brunsberdze (Bra- 
According to the most recent estimate, when migration was at its peak in the fourth decade of the seventeenth century, the diaspora of predominantly Scottish immigrants consisted of perhaps as many as 5,000 to 7,000 individuals. ${ }^{29}$ Large congregations formed around the local Calvinist parishes in the major cities of Poland-Lithuania in Gdańsk, Kraków, Elbląg, Lublin, Wilno and Kieydany. Several accounts of the Scottish expatriate community, written by Scottish and English travellers like Mundy ${ }^{30}$, Bargrave ${ }^{31}$, and Roberts $^{32}$ were published in Britain.

Not all English and Scottish writers looked favourably on Polish tolerance, however. The previously mentioned Barclay, author of the famous Icon Animorum (1614), while describing the character and manners of the European nations reserved very harsh comments for the national traits of Poles. In particular, Barclay heavily criticised their religious views and practices. ${ }^{33}$

They are [the Poles] wedded strangely to their own fancies; nor doe they take to themselues a greater licentiousnesse in manners and unciuill conversations, then in their opinions of Religion, and heauenly matters; of which, euery man without any feare, will both thinke and speake as himselfe likteth: Which proceedeth surely from an abominable confidence they haue of themselues, and are ashamed to learne the best wisedom from another mans direction, from

niewie) 1579-1623, eds. Marek Inglot SJ and Ludwik Grzebień SJ (Kraków: WSFP “Ignatianum”, 1998); Die Schüler des Braunsberger Gymnasiums von 1694 bis 1776 nach dem Album Scholasticum Brunsbergens: in einem Anhang; Frühere Schüler der Anstalt seit 1640; Frühere Schüler der Anstalt seit 1640, ed. Georg Lühr (Braunsberg: Druck der Ermländischen Zeitungs- und Verlagsdruckerei, 1934); Cf. 'List of Scottish Pupils at the Jesuit-Seminary at Braunsberg (1579-1642)', Thomas Alfred Fischer, The Scots in Germany: Being a Contribution Towards the History of the Scots Abroad (Edinburgh: Otto Schulze, 1902), 298-299.

29 Bajer, Scots in the Polish-Lithuanian Commonwealth, op. cit., 102.

30 Peter Mundy, The travels of Peter Mundy 1597-1667, ed. John Keast (Redruth: Dyllansow Truran, 1984); idem, The travels of Peter Mundy, in Europe and Asia, 1608-1667, ed. Richard Carnac Temple (Cambridge: Printed for the Hakluyt Society, 1907-36), vol. 4.

31 Robert Bargrave, The travel diary of Robert Bargrave: Levant merchant (1647-1656) ed. Michael G. Brennan, (London: Hakluyt Society, 1999), 125, 146-147.

32 Lewes Roberts, The merchants mappe of commerce wherein, the universall manner and matter of trade, is compendiously handled. The standerd and currant coines of sundry princes, observed. The reall and imaginary coines of accompts and exchanges, expressed. The naturall and artificiall commodities of all countries for transportation declared. The weights and measures of all eminent cities and tovvnes of traffique, collected and reduced one into another; and all to the meridian of commerce practised in the famous citie of London. By Lewes Roberts, merchant. Necessary for all such as shall be imployed in the publique affaires of princes in forreigne parts; for all gentlemen and others that travell abroad for delight 386 or pleasure, and for all merchants or their factors that exercise the art of merchandizing in any part of the habitable world (London: Printed by R. Oulton, Eliot's Court Press, Thomas Harper, and Felix Kingston] for Ralph Mabb, MDCXXXVIII [1638]), 166.

33 Nicola Royan, 'Barclay, John (1582-1621)', Oxford Dictionary of National Biography (Oxford: Oxford University Press, Sept 2004); online edn, Jan 2008 [http://www.oxforddnb.com/view/article/1342, accessed 15 May 2010]. 
hence is, that their mindes at this day are diuided into many schismes, and haue among them all the heresies which polluted former times... ${ }^{34}$

Although the extent to which this negative stereotype affected the perception of Poles in Britain is open for discussion - the book had numerous reprints - the real shift of the public opinion towards the religious situation in Poland-Lithuania became apparent in the 1650s. At its root was the disastrous Swedish invasion and occupation of the country from 1655 to 1660, better known in Polish history as Potop (the Deluge), which was responsible for increasing differences between denominations (confessionalisation). A large group of dissidents - amongst them Scots and English who were potential supporters of Cromwell, who himself favoured the Swedes - were accused of conspiring with the enemy.

The accusations were not ill-founded. A number of first-hand reports which appeared in the English press during Cromwell's protectorate strongly indicate Polish Scots' approbation towards the invaders. News about the conflict reaching Britain was, it seems, sent directly to London by Scottish merchants from Poland. ${ }^{35}$ While the majority of the intelligence originated in Gdańsk, correspondence was also sent from Elbląg, Głogów, Cracow and Warsaw. ${ }^{36}$ Furthermore, as the example of the Scottish Reformed of Cracow indicates, many of the Scots not only offered counsel but actually spied for the Swedes, possibly even prior to the invasion. It appears that some Scots also assisted the occupiers in the government. They were involved in extracting compulsory contributions from the local inhabitants during the Swedish rule and collaborated in the looting of Catholic churches. ${ }^{37}$

The eventual victory of the revolt against Swedish rule, under the banner of a defence of Roman Catholicism, did more damage to the Protestant cause than perhaps the Counter-Reformation itself. A conventional notion which equated 'heretics' to traitors led to retaliation, like the destruction of Leszno and the church in Skoki, and the formation of a society less tolerant than before. Fearing retribution, many Scots and English fled Poland-Lithuania along with the retreating Swedish army. ${ }^{38}$

34 Barclay, Icon animorum, op. cit., 187-188.

35 Mercurius Politicus Comprising the Summ of All Intelligence (London, England, Thursday, April 10, 1656). Issue 305, 6097; Publick Intelligencer (1655) (London, England, Monday, April 7, 1656), Issue 28, 472.

36 For example a report from Cracow appeared in Publick Intelligencer (1655) (London, England, Monday, April 14, 1656), Issue 29, 486.

37 Waldemar Kowalski, Wielka imigracja. Szkoci w Krakowie i Matopolsce w XVI-pierwszej potowie XVII wieku (Kielce: Wydawnictwo Uniwersytetu Humanistyczno-Przyrodniczego im. Jana Kochanowskiego, 2010), 168-173; Cf. detailed information about Scottish involvement in the anti-Polish espionage networks in the early seventeenth century has been given by Murdoch. Murdoch, Network North, op cit., 251-279.

38 A similar argument was advanced by Mierzwa. Mierzwa, Anglia a Polska, op. cit., 193. 
There is no denial that tensions between different creeds did exist in Poland-Lithuania prior to the 'Swedish Deluge'. It has been well documented that despite the prevailing spirit of tolerance, the majority of members of all denominations believed that only their own doctrine pointed the way towards eternal salvation. Gilbert, who in 1638 illustrated the peaceful coexistence of different denominations in Vilnius, in the same report dismissively characterised other non-Protestant creeds as being 'either of Idolatory, superstition or errours, in league and consanguity joyned with the Papists. ${ }^{39}$ Moreover, in conclusion to his testimony, while condemning the actions of Catholics in Vilnius, he contradictorily criticised the religious tolerance. Gilbert emphatically encouraged the establishment to 'exterminate and extirpate' from the British Isles all the non-Reformed churches (most of all, the Romanists), other Christian sects and non-Christians. ${ }^{40}$ His opinions were symptomatic of views held by the majority of followers of each of the respective creeds. This largely explains why, at times, there were indeed more serious, well-documented discriminations and persecutions, some of which also involved the immigrants from Britain. It should be mentioned that confessional divisions also plagued the expatriate Scottish community. An inquiry into the organization of Scots in Poland showed that their brotherhoods, controlled by the Protestants, discriminated against their 'Popish' compatriots. ${ }^{41}$

While the reports of sporadic denominational clashes in Poland-Lithuania received relatively little attention in either England or Scotland up until the fourth decade of the seventeenth century, the interest in the situation of the Protestants in Poland-Lithuania heightened substantially during the second half of the seventeenth century. ${ }^{42}$ This increase has been linked to the success of the Counter-Reformation in Poland-Lithuania and the alleged growing influence of the Jesuits on the kingdom's social, political and cultural life. ${ }^{43}$ Consequently, once favourable opinions of Poland-Lithuania, such as the 'Mother and

39 Gilbert, Nevves from Poland, op. cit., 7.

40 "...let us be carefull in our best devotion and prayers to sollicite and implore the favourable assistance, and gracious presence of the Almighty, who hath the hearts of Kings and great men in his hands, urning them (like the rivers of water) which way he listeth; That he may be pleased so to affect and dispose the hearts of the Peers and Princes, Magistrates of this Land, that they may speedily bethinke themselves of some opportune way and means, whereby all fractions, and factions, schismes, separations, sidings and backslidings, contentions, combustions, confusions, prevarications, finally all Antichristian, polypragmaticall, tyrannicall, and trecherous heresies, schismes, practices and professions, and enterprises may be quite, or at least as much as is possible, abolished and removed from the body and the bounds of this Monarchie, and that all his Majestis subjects here and elsewhere, may from henceforth concurre and consent, in unity of mind, opinion, judgement...", ibid., 29-30.

41 'Records of the Court of Investigation in Cracow (1603)', Papers Relating to the Scots in Poland 1576-1593, ed. Francis Archibald Steuart (Edinburgh: Scottish Historic Society, 1915), 77; Stanisław Tomkowicz, 'Przyczynek do historii Szkotów w Krakowie i w Polsce', Rocznik Krakowski, 2 (1899), 164.

42 The attacks on the Protestant church in Kraków in 1587 and 1591 (the author mistakenly noted 1592) have received a low key treatment in the Relation of 1598. - 'A Relation of the State of Polonia', 64.

43 Beata Cieszyńska, 'Polish Religious Persecution as a Topic in British Writing in the Seventeenth and Ear- 
Nurse for the youth and younglings of Scotland ${ }^{344}$ were gradually replaced in English and Scottish literature by descriptions such as the 'Popish Clergie's' kingdom. ${ }^{45}$ Satires aimed at Poland-Lithuania like that of Sir James Sempill's The Packman Pater Noster or A Dialogue betwixt a Chapman and a Priest (1624) or Richard Burridge's An Apostate Prince or a Satyr Against the Present King of Poland (1700), gained notoriety ${ }^{46}$ Along with these, reports of discrimination and persecution of Polish Protestants, such as Gilbert's Nevves from Poland (1641), began to dominate the portrayal of the kingdom. This negative depiction of the Polish-Lithuanian Commonwealth has also been linked to the growth of anti-Catholicism at all levels of English and Scottish society, which is believed to be one of the most noticeable characteristics of the British Isles in the seventeenth century. Moreover, it appears that many publications describing and magnifying the maltreatment of dissenters by those 'addicted to the Roman See' in Continental Europe were issued for propagandist purposes, in the same way as graphic descriptions of the massacres of Protestant settlers in 1641 were designed to legitimize the cruel treatment of Irish Catholics. ${ }^{47}$ It can be argued that the sudden rise in popularity of such texts coincided with Cromwell's attempts to justify atrocities committed by his army in Ireland during the English Civil War (1641-1651) and especially after the massacre at Drogheda. ${ }^{48}$ Anxious about the public reaction to this particular episode and displeased by the onslaughts of both radical pamphleteers and Royalist newspapers, in September 1649 Parliament passed a rigorous printing act which effectively put an end to all the licensed newspapers. ${ }^{49}$ The Parliament-authorized newspapers,

ly Eighteenth Century', Britain and Poland-Lithuania: Contact and Comparison from the Middle Ages to 1795, eds. Richard Unger, Jakub Basista (Leiden: Brill, 2008), 243-244.

44 Later he also calls it "the mother of our commons, and the first commencement of all our best merchants' wealth, or at least most part of them." - William Lithgow, The Totall Discourse of the Rare Adventures and Painefull Peregrinations of Long Nineteene Yeares Travayles from Scotland to the Most Famous Kingdomes in Europe, Asia and Africa [London: Nicholas Okes, 1632], reprint, (Glasgow: James MacLehose and Sons 1906), 368.

45 Gilbert, Nevves from Poland, op. cit..

46 [James Sempill], A Pick-tooth for the Pope: or, The pack-mans pater noster. Set downe in a dialogue, betwixt a pack-man, and a priest. Translated out of Dutch by S.I.S. and newly augmented and enlarged by his son, R.S. (Glasgow, 1642); Richard Burridge, An Apostate Prince or a Satyr against the Present King of Poland (London, 1700), cited in Cieszyńska, 'Polish Religious Persecution', 244-247, 255.

47 Michael Ó Siochrú, 'Atrocity, Codes of Conduct and the Irish in the British Civil Wars 1641-1653', Past \& Present, 195 (2007), 67-68; Cf. Mierzwa, Anglia a Polska, op. cit., 193.

48 Cf. Toby Christopher Barnard, 'Planters and Policies in Cromwellian Ireland', Past \& Present, 61 (1973), 40; Robert Clifton, 'Fear of Popery', The Origins of the Civil War, ed. Conrad Russell (London: Macmillan, 1973), 152-153; Robert Clifton, 'The Popular Fear of Catholics During the English Revolution', Rebellion, Popular Protest and the Social Order in Early Modern England, ed. Paul Slack (Cambridge: Cambridge University Press, 1984); Barbara Donagan, 'Codes and Conduct in the English Civil War', Past \& Present, 118 (1988), 65-95; Walter D. Love, 'Civil War in Ireland. Appearances in Three Centuries of Historical Writing', Emory University Quarterly (1966), 57-62; Michael Ó. Siochrú, 'Atrocity', op. cit., 67-68.

49 'Newspapers, origins of', The Oxford Companion to English Literature, $5^{\text {th }}$ edition, ed. Margaret Drabble (Oxford: Oxford University Press, 1985), 696. 
Moderate Intelligencer, Mercurius Politicus and Publick Intelligencer, as expected, presented an anti-Polish profile.

One of the first publications overemphasizing the mistreatment of Protestants coming out of Poland-Lithuania was the previously mentioned Gilbert's description of 'the cruell practice of the Popish Clergie against the Protestants', an account of the assault on the Reformed church in Vilnius in 1639. According to Mierzwa, Gilbert's Nevves from Poland (1653) not only increased English and Scottish awareness of the situation of the Polish Protestants but also rekindled an interest in Polish anti-Catholic thought. ${ }^{50}$ This is perhaps why exposure was also given to a description by Jan Ámos Komenský of the destruction of Leszno in April 1656. ${ }^{51}$

Although the information about religious affairs in the English press was eclipsed by politics and economics, sporadic events were nevertheless reported. In February 1656 an exaggerated account of the retaliation against the Protestants of Wielun for accepting the Swedes appeared in the London-published Mercurius:

...Great tyranny is used in Great Poland and about Cracovia, for, when the Pols fall upon the Swedish Souldiers, never were greater Butcheries acted: The children are divided and cut under like so many sheep, womens breasts are cut off, and afterwards dissected in four Quarters, they take our Protestant Ministers, and cut off their hands and feet, and aftewards chopp of their heads, divide the body into severall quarters; in the mean time the Hoggs do dragg along the bowels in the streets, and that the villainous actors may not miss the Pleasure of the Tragedy, they fling Corn upon the slain mens flesh, and thus let the Hoggs run into it: Such a Tragicomedy was lately acted at Wielun, where many of my Lord Steinbocks Regiment, being raised about Stettin, have been destroyed in this manner. ${ }^{52}$

While reporting about the change of fortunes in the Polish-Swedish war, an alarmist prediction about the religious situation in Poland-Lithuania appeared in the Publick Intelligencer. An informant from a largely Protestant Gdańsk, which sided throughout the conflict with the Polish Crown, speculated that once the Swedish invasion was totally repelled the 'Protestants are to be rooted out in all Poland.53 In such circumstances, a voice questioning the notion that the Swedes were promoting the Protestant cause in Poland-Lithuania was, it seems, lost in bleak prognosis for the Polish and Lithuanian Calvinists. ${ }^{54}$

50 Mierzwa, Anglia a Polska, op. cit., 193.

51 John Amos Komenský, Lesnae excidium, anno MDCLVI in Aprili factum, fide historica narratum (Amsterdam, 1656), cited in Mierzwa, Anglia a Polska, op. cit., 194.

52 'A report from Breslau, dated 21 February 1656', Mercurius Politicus Comprising the Summ of All Intelligence (London, Thursday, February 21, 1656); Issue 298, 5987.

53 Publick Intelligencer (1655) (London, Monday, May 5, 1656); Issue 32,. 540-41.

54 Anon., The Promotion of the Protestant cause in Poland by the ármes of His Majesty the King of Sweden / fully translated (London printed: [s.n.], 1659). 
The predictions must have been amplified by direct appeals made by the Polish Reformed Church to the English monarch or other organisations for financial aid and political support. Several such pleas have been recorded. In 1657, Samuel Bogusław Chyliński, a minister from Lithuania, sought and received financial assistance from the Reverend Doctors of the Oxford University. ${ }^{55}$ A dramatic supplication to the English and Scottish Protestants by Kraiński was published in 1661 .

Our very Neighbours do hate, and persecute the Remenant of us still, with much eagerness. As our foreign Enemies did: they deprive us of our Churches yet remaining [...] our Ministers are banished; and such, as remain are beaten, and misused: the Threatnings of our total Exilement are encreased. [...] Look therefore, we beseech you, upon us, as Objects of Pitie, and for the Love of God, for the sacred bonds of unity in Christ Jesus, stretch forth your hands [...] Send suitable compforts to those, that are comfortless... ${ }^{56}$

By the late 1650s the news about the worsening situation of the Protestants in Poland-Lithuania, amongst them those of Scottish or English extraction, reached a wider audience in the British Isles. In response, first Cromwell ${ }^{57}$, and later King Charles II announced collections towards the relief of the Protestant churches..$^{58}$ Aid in providing appropriate education for ministers from Poland-Lithuania was also offered. In 1680, the Reformed of Greater Poland acquired $£ 200$ for sending four students to universities in England ${ }^{59}$, while in 1681 the Calvinists from Little Poland were offered two places at the college in Glasgow. ${ }^{60}$

55 Chyliński undertook a project of translating the Bible into Lithuanian. - Samuel Bogusław Chyliñski, An account of the translation of the Bible into the Lithvanian tongve, into which language the Scriptures were as yet never translated with a copy of the testimoniall given to the translator: and of the approbation of his undertaking, by several reverend doctors of divinity, with the professors of the same, and other persons of note in the University of Oxford, November 15, 1659 (Oxford: printed by Hen. Hall ..., 1659), 5-6.

56 John de Kraino Kraiński, A relation of the distressed state of the church of Christ professing the protestant religion in the great dukedom of Lithuania, presented to the view of all compassionate Christians (London: printed in the year of our salvation, 1661).

57 A declaration of His Highness, for a collection towards the relief of divers Protestant churches driven out of Poland; and of twenty Protestant families driven out of the confines of Bohemia (London: printed by Henry Hills, and John Field, Printers to His Highness, 1658). Cf. 'John Thurloe to the lord embassador Nieuport, dated Westminster, 19th April, 1658. [N. S.]', A Collection of the State Papers of John Thurloe, ed. Thomas Birch (London, 1742), vol. 7 (March 1658 - May 1660), 61-62.

58 Charles II, Letters patent for a collection for the Protestants of Lithuania (London: Printed by John Bill and Christopher Barker, printers to the Kings most Excellent Majesty, 1661).

59 Mierzwa, Anglia a Polska, op. cit., 197.

60 "In ansuer to the letter direct to the magistratis and counsell of this burgh be the ministeris in Litle Poland, it is concluded that ane letter be sent in name of the toun to James Cornwall of Bonhard, to be transmitted to the saids ministeris, declareing that the toun hes condescended and aggried to accept of such twa young men as the said ministeris shall think fitt to send hither for the colledge, and that they will mentain and keep them at the colledge ay and quhill they shall be found qualified for being ministeris of the gospell." - 'Ansuer to the 
Some of the earlier mentioned accounts have in turn inspired other works. A description of the destruction of Leszno by Komenský reappeared some forty years after it happened in a well-read register of persecutions against the Protestants compiled by Clarke. ${ }^{61}$ Later still, it was repeated and further exaggerated in at least two other London-published volumes, The Scarlet Whore, or the cruelties of the Church of Rome (1690), and subsequently in Martyrs in flames, or, Popery (in its true colours) displayed (1693). ${ }^{62}$

\section{CONCLUSION}

The Polish-Lithuanian Commonwealth and the religious developments therein were not unfamiliar to an educated seventeenth century English or Scottish person. A range of accounts available in Britain presented the public with an array of opinions and points of view. As those changed over time, so did the perceptions formed in the process. The religious toleration in Poland-Lithuania and the ideology of the Polish Antitrinitarians captivated the attention of the public in the British Isles until well into the 1630s, leaving a lasting impression on English and Scottish philosophy and theology. The fame of the Polish Brethren, however, and interest shown in peaceful coexistence of various creeds in Poland ebbed after the triumph of Protestantism in England and Scotland, and the Counter-Reformation in the Commonwealth. From the 1640s onwards, impressions of Poland-Lithuania from the English and Scottish perspective were primarily formed based on religious conflict and denominational differences. The earlier admired toleration began to be seen as a sign of anarchic religious liberty, a weakness; something to be, as Gilbert insisted, 'abolished and removed from the body and the bounds' of the English monarchy. ${ }^{63}$ In 1683 , in the same

ministeris of Litle Polandis letter, dated 20 December 1681', cited in Extracts from the Records of the Burgh of Glasgow, ed. James David Marwick (Glasgow: Scottish Burgh Record Society 1905), vol. 3: 1663-1690, 308.

${ }_{61}$ Samuel Clarke, A generall martyrologie containing a collection of all the greatest persecutions which have befallen the church of Christ from the creation to our present times, both in England and other nations: whereunto are added two and twenty lives of English modern divines... : as also the life of the heroical Admiral of France slain in the partisan massacre and of Joane Queen of Navar poisoned a little before / by Sa. Clarke (London: printed by Tho. Ratcliffe for Thomas Underhill and John Rothwell, 1660), 452-462.

62 Anon., The Scarlet Whore, or the cruelties of the Church of Rome for many hundred years past dispay'd in Piedmnt, Bohemia, Germany, Poland, Lithuania, France, Italy, Portugal, Holland, Scotland, Ireland and England etc. (London, 1690), cited in Mierzwa, Anglia a Polska, op. cit., 194; Martyrs in flames, or, Popery (in its true colours) displayed. Being a brief relation of the horrid cruelties and persecutions of the Pope and Church of rome for many hundred years past, to this present age, inflicted upon Protestants in Piedmont ... : With an abstract of the cruel persecution lately exercised upon the Protestants in France and Savoy, in the year 1686 and 1687.: Together with a short account of Gods judgment upon popish persecutors. / Published for a warning to all Protestants, [] what they must expect from that bloody generation of Antichristians. By R.B. (London: printed for Nath. Crouch ..., [1693]), 42-45.

63 Gilbert, Nevves from Poland, op. cit., 30. 
spirit, an anonymous Tory propagandist made Poland the setting for a satirical scheme of toleration for Presbyterian nonconformists. ${ }^{64}$ Furthermore, despite the fact that until the end of the seventeenth century various creeds were tolerated and continued their relatively peaceful existence in Poland-Lithuania, English and Scottish observers were more inclined to note negative stereotypes. Various publications circulating during this period, as well as oral commentaries of the returning migrants, must have consolidated the image of Poland-Lithuania as a land suffering from Catholic fanaticism. Even the widely published late seventeenth century reports of the victory over the Turks by Jan III Sobieski at the Siege of Vienna were unlikely to have had much impact on the negative portrayal of Poland. ${ }^{65}$ The Commonwealth may have been proclaimed the Antemurale Christianitatis, but at the same time it was described as a staunchly Catholic state, hostile to the Protestants. The denominational differences between the two states that emerged deepened in the following century, further reinforcing the negative perceptions of Poland-Lithuania, and estranging it in the minds of English and Scottish Protestants. ${ }^{66}$

\section{BIBLIOGRAPHY}

A declaration of His Highness, for a collection towards the relief of divers Protestant churches driven out of Poland; and of twenty Protestant families driven out of the confines of Bohemia (London: Printed by Henry Hills, and John Field, Printers to His Highness, 1658).

64 Anon., The Saints liberty of conscience in the new kingdom of Poland: proposed for the consolation of the distressed (Warszawa [i.e. London]: [s.n.], 1683).

65 Anon., The Christian conquest. Being an account of the great overthrow of the Turks before the imperial city of Vienna, in Germany, who, by Gods blessing and the happy conduct of the King of Poland, the Duke of Lorain, \& $c$ were totally routed; having lost near one hundred thousand men in the field, sixty thousand tents and two millions of money in the Grand Visiers tent. Ec. Tune of, When the King injoys his own again ([London]: printed for J. Wright, J. Clark, W. Thackery, and T. Passinger, 1681-1684); Anon., True news of another bloody battle, of the King of Poland with the Turks and also an account of the taking of the Great Vizier and divers other Turkish lords, and great commanders, and of the redeeming many thousand Christian captives from slavery (London: printed for R. P., 1683); H. G., Scanderbeg redivivus an historical account of the life \& actions of the most victorious Prince John III, K. of Poland: containing an exact and succinct series of affairs from his cradle to this present day, with a particular account of the many great and signal victories obtained by him against the Turks, from the time he was first made crown-general, and afterwards elected King of Poland: dedicated to the Lord Landsdowne, Count of the Holy Empire (London: printed by H.C. for Tho. Malthus..., 1684). John III Sobieski, A speech delivered by the King of Poland to his army before the battle, September 12th, 1683 ([London: printed by N. Thompson ..., 1683); A. Whitebrook, A true copy of a letter from an English gentleman in the Emperour's army, to an English officer in Holland concerning the total rout of the Turks by the united forces of the Christians, commanded in person by the Emperour, the King of Poland, and Duke of Lorain (London: Printed by E. Mallet, [1683?]).

66 Larry Wolff, Inventing Eastern Europe: The Map of Civilization on the Mind of the Enlightenment (Stanford, Calif.: Stanford University Press, 1994). 
Anon., The Christian conquest. Being an account of the great overthrow of the Turks before the imperial city of Vienna, in Germany, who, by Gods blessing and the happy conduct of the King of Poland, the Duke of Lorain, Ec were totally routed; having lost near one hundred thousand men in the field, sixty thousand tents and two millions of money in the Grand Visiers tent. \&c. Tune of, When the King injoys his own again ([London]: printed for J. Wright, J. Clark, W. Thackery, and T. Passinger, 1681-1684).

Anon., The Promotion of the Protestant cause in Poland by the ármes of His Majesty the King of Sweden (London printed: [s.n.], 1659).

Anon., The Saints liberty of conscience in the new kingdom of Poland: proposed for the consolation of the distressed (Warszawa [i.e. London]: [s.n.], 1683).

Anon., True news of another bloody battle, of the King of Poland with the Turks and also an account of the taking of the Great Vizier and divers other Turkish lords, and great commanders, and of the redeeming many thousand Christian captives from slavery (London: printed for R. P., 1683).

'Ansuer to the Ministeris of Litle Polandis Letter, dated 20 December 1681', cited in Extracts from the Records of the Burgh of Glasgow, ed. James David Marwick (Glasgow, 1905), vol. 3: 1663-1690, 308.

'A Relation of the State of Polonia and the United Provinces of that Crown, Anno 1598', Elementa ad fontium editiones, Vol. XIII: Res polonicae ex archivio Musaei Britannici Pars 1, ed. Carolus H. Talbot (Roma: Institutum Historicum Polonicum Romae, 1965).

'A Report from Breslau, dated 21 February 1656', Mercurius Politicus Comprising the Summ of All Intelligence (London, Thursday, February 21, 1656); issue 298, 5987.

Barclay John, Ioannis Barclaii Icon animorum, Londini: Ex offcina Nortoniana apud Iohanne Billium, M.DC.XIV. [1614].

Bargrave Robert, The Travel Diary of Robert Bargrave: Levant Merchant (1647-1656), ed. Michael G. Brennan (London: Hakluyt Society, 1999).

Catechesis Ecclesiarum quae in Regno Poloniae et magna Ducatu Lithuaniae, et aliis ad istud Regnum pertinentibus Provinciis, affirmant, neminem alium, praeter Patrem Domini nostri Jesu Christi, esse illum unum Deum Israëlis: Hominem autem illum Jesum Nazarenum, qui ex Virginenatus est, nec alium, praeter aut ante ipsum, Dei Filium unigenitum, et agnoscunt et confitentur. Ante annos quatuor Polinicè, nunc verò etiam Latinè edita (Racoviæ, 1609).

Catechesis ecclesiarum quae in regno Poloniae \& magno Ducatu Lithuaniae, \& aliis ad istud regnum pertinentibus provinciis, affirmant, neminem alium praeter patrem Domini nostri Iesu Christi, esse illum unim Deum Israëlis: hominem autem illum Iesum Nazarenum, qui ex virgine natus est, nec alium, praeter aut ante ipsum, Dei filium unigenitum \& agnoscunt \& confitentur. Cui accedit Fausti Socini Senensis vita. Et dissertatio operibus suis ab Equite Polono praemissa. Cum catalogo operum ejusdem Fausti Socini. Dissertatio quam Fausti Socini operibus praemitti voluit. Dissertatio quam Fausti Socini operibus praemitti voluit. (Racoviae [i.e. London: printed by William Dugard], anno Domini M.DC.LI. [1651]).

Charles II, Letters patent for a collection for the Protestants of Lithuania (London: printed by John Bill and Christopher Barker, printers to the Kings most Excellent Majesty, 1661).

Chyliński Samuel Bogusław, An account of the translation of the Bible into the Lithvanian tongve, into which language the Scriptures were as yet never translated with a copy of the testimoniall given to the translator: and of the approbation of his undertaking, by several reverend doctors of divinity, with the professors of the same, and other persons of note in the University of Oxford, November 15, 1659 (Oxford: printed by Hen. Hall..., 1659). 
Clarke Samuel, A generall martyrologie containing a collection of all the greatest persecutions which have befallen the church of Christ from the creation to ourpresent times, both in England and other nations: whereunto are added two and twenty lives of English modern divines ... : as also the life of the heroical Admiral of France slain in the partisan massacre and of Joane Queen of Navar poisoned a little before / by Sa. Clarke (London: printed by Tho. Ratcliffe for Thomas Underhill and John Rothwell, 1660).

Gilbert Eleazar, Nevves from Poland wherein is declared the cruell practice of the popish clergie against the Protestants, and in particular against the ministers of the city of Vilna, in the great dukedome of Lithuania, under the governement of the most illustrious prince, Duke Radziwell / faithfully set downe by Eleazar Gilbert ... (London: by E.P. for Nathanael Butter, and are to be sold at his shop, 1641).

Gordon Patrick L., 'Diary 1659-1667', Russian State Archive of Military History, Moscow, Fond 846, Op. 15, Vol. 1-6.

H. G., Scanderbeg redivivus an historical account of the life \& actions of the most victorious Prince John III, K. of Poland: containing an exact and succinct series of affairs from his cradle to this present day, with a particular account of the many great and signal victories obtained by him against the Turks, from the time he was first made crown-general, and afterwards elected King of Poland: dedicated to the Lord Landsdowne, Count of the Holy Empire (London: printed by H.C. for Tho. Malthus..., 1684).

John III Sobieski, A speech delivered by the King of Poland to his army before the battle, September $12 t h, 1683$ ([London]: printed by N. Thompson ..., 1683).

'John Thurloe to the lord embassador Nieuport, dated Westminster, 19th April, 1658. [N. S.]', A collection of the State Papers of John Thurloe, ed. Thomas Birch (London, 1742), vol. 7 (March 1658 - May 1660), 61-62.

Komenský, John Amos, Lesnae excidium, anno MDCLVI in Aprili factum, fide historica narratum (Amsterdam, 1656).

Kraino Kraiński de John, A relation of the distressed state of the church of Christ professing the protestant religion in the great dukedom of Lithuania, presented to the view of all compassionate Christians (London: printed in the year of our salvation, 1661).

Lithgow William, The Totall Discourse of the Rare Adventures and Painefull Peregrinations of long Nineteene Yeares Travayles from Scotland to the most famous Kingdomes in Europe, Asia and Africa [London: Nicholas Okes, 1632], reprint (Glasgow: James MacLehose and Sons, 1906).

Martyrs in flames, or, Popery (in its true colours) displayed. Being a brief relation of the horrid cruelties and persecutions of the Pope and Church of rome for many hundred years past, to this present age, inflicted upon Protestants in Piedmont ... : With an abstract of the cruel persecution lately exercised upon the Protestants in France and Savoy, in the year 1686 and 1687.: Together with a short account of Gods judgment upon popish persecutors. / Published for a warning to all Protestants, [] what they must expect from that bloody generation of Antichristians. By R.B (London: printed for Nath. Crouch ..., [1693]).

Mercurius Politicus Comprising the Summ of All Intelligence (London, England, Thursday, April 10, 1656), issue 305, 6097.

Moderate Intelligencer (London, Thursday, April 20, 1648), issue 162, 1282.

Mundy Peter The travels of Peter Mundy 1597-1667, ed. John Keast (Redruth: Dyllansow Truran, 1984).

Mundy Peter, The travels of Peter Mundy, in Europe and Asia, 1608-1667, ed. Richard Carnac Temple (Cambridge: Printed for the Hakluyt Society, 1907-1936), vol. 4. 
Przypkowski Samuel, Dissertatio de pace, \&r. Or, A discourse touching the peace \& concord of the Church. Wherein is elegantly and acutely argued, that not so much a bad opinion, as a bad life, excludes a Christian out of the kingdom of heaven; and that the things necessary to be known for the attainment of salvation, are very few and easie: and finally, that those, who pass amongst us under the name of hereticks, are notwithstanding to be tolerated (London: printed by Ja: Cottrel, for Rich. Moone, at the seven stars in Paul's Church-yard., 1653).

Przypkowski Samuel, Dissertatio de pace, \&c. Or, A discourse touching the peace and concord of the Church. Wherein is elegantly and acutely argued, that not so much a bad opinion, as a bad life, excludes a Christian out of the kingdom of heaven: and that the things necessary to be known for the attainment of salvation, are very few and easie: and finally, that those, who pass amongst us under the name of hereticks, are notwithstanding to be tollerated (London: printed [by J.G. from Thomas Malthus], 1684).

Przypkowski Samuel, Dissertio de pace, Sc, or, A discourse touching the peace and concord of the Church wherein First, is elegantly and accurately argued, that its not so much a bare error in opinion ... secondly, that the things necessary ... Lastly, that those who pass amongst us ... (London: printed and sold by Andrew Sowle ..., 1688).

Przypkowski Samuel, The life of that incomparable man, Faustus Socinus Senensis, described by a Polonian knight. Whereunto is added an excellent discourse, which the same author would have had premised to the works of Socinus; together with a catalogue of those works (London: printed for Richard Moone, at the seven Stars in Pauls Church-yard, neer the great north-doore., 1653).

Publick Intelligencer (1655) (London, England, Monday, April 7, 1656), issue 28, 472.

Publick Intelligencer (1655) (London, England, Monday, April 14, 1656), issue 29, 486.

Publick Intelligencer (1655) (London, Monday, May 5, 1656); issue 32, 540-41.

'Records of the Court of Investigation in Cracow (1603)', Papers Relating to the Scots in Poland 1576-1593, ed. Francis Archibald Steuart (Edinburgh: Scottish Historic Society, 1915).

Roberts Lewes, The merchants mappe of commerce wherein, the universall manner and matter of trade, is compendiously handled. The standerd and currant coines of sundry princes, observed. The reall and imaginary coines of accompts and exchanges, expressed. The naturall and artificiall commodities of all countries for transportation declared. The weights and measures of all eminent cities and tovvnes of traffique, collected and reduced one into another; and all to the meridian of commerce practised in the famous citie of London. By Lewes Roberts, merchant. Necessary for all such as shall be imployed in the publique affaires of princes in forreigne parts; for all gentlemen and others that travell abroad for delight 386 or pleasure, and for all merchants or their factors that exercise the art of merchandizing in any part of the habitable world (London: printed by R. O[ulton, Eliot's Court Press, Thomas Harper, and Felix Kingston] for Ralph Mabb, MDCXXXVIII [1638]).

Speed John, A prospect of the most famous parts of the vvorld Viz. Asia, 3 Affrica, 5 Europe, 7 America. 9 Vith these kingdomes therein contained, Grecia, 11 Roman Empire, 13 Germanie, 15 Bohemia, 17 France, 19 Belgia, 21 Spaine, 23 Italie, 25 Hungarie, 27 Denmarke, 29 Poland, 31 Persia, 33 Turkish Empire, 35 Kingdo: of China, 37 Tartaria, 39 Sommer Ilands, 41 Ciuill Warres, in England, Wales, and Ireland. You shall finde placed in the beginning of the second booke marked with these [3 asterisks in triangle formation] and (5) Together with all the prouinces, counties, and shires, contained in that large theator of Great Brittaines empire. Performed by Iohn Speed (London: printed by Iohn Dawson for George Humble, and are to be sold at his shop in Popes-head Pallace, 1631). 'The banishment of Arianism out of Polonia: with the entrtainment of a Polonian Embassador in Muscovia', Moderate Intelligencer, 119 (Thursday, June 17, 1645), 1134-1135. 
The Racovian catechisme vvherein you have the substance of the confession of those churches, which in the kingdom of Poland, and great dukedome of Lithuania, and other provinces appertaining to that kingdom, do affirm, that no other save the Father of our Lord Jesus Christ, is that one God of Israel, and that the man Jesus of Nazareth, who was born of the Virgin, and no other besides, or before him, is the onely begotten Sonne of God, [Apparently translated from the Latin version] (Printed at Amsterledam [sic]: for Brooer Janz, 1652).

Universalium sacrae regiae majestatis Poloniae \& Sueciae, \&c. ad dissidentes ab Ecclesia Catholica Romana: et literarum illustrissimi ac Reverendissimi Dn. Archiepiscopi Gnesnensis regni primatis, Sc. ad eosdem: tum ad universales S.R. majestatis deputorum ab eclesiis regni \& M.D. Lithuan. evangelicis Orlae congregatorum, supplicis libelli. Ac eorundem ad literas illustrissimi \&oc. Dn. Archiepiscopi responsionis, ex originalibus fidelis transcriptio. Feb. 15. 1644. Imprimatur. Ja. Cranford (Londini: Excudebat E.G. impensis Johannis Rothwell, sub signo Solis in Coemeterio Paulino, 1645).

Votes of Parliament touching the Book commonly called The Racovian Catechisme (London: Printed by John Field, Printer to the Parliament of England, 1652).

Whitebrook A., A true copy of a letter from an English gentleman in the Emperour's army, to an English officer in Holland concerning the total rout of the Turks by the united forces of the Christians, commanded in person by the Emperour, the King of Poland, and Duke of Lorain (London: printed by E. Mallet, [1683?]).

\section{Secondary sources}

Ayre Michael Broun, The Scottish Community in the Grand Duchy of Lithuania, 1630-1750 (Kaunas: Humanitas, 2020).

Bajer Peter Paul, Scots in the Polish-Lithuanian Commonwealth in the Sixteenth to the Eighteenth Centuries: The Formation and Disappearance of an Ethnic Group (Leiden: Brill, 2012).

Barnard Toby Christofer, 'Planters and policies in Cromwellian Ireland', Past \& Present, 61 (1973), 31-69.

Bartel Oskar, Jan Easki (Warszawa: Neriton, 1999).

Bendall Sarah, 'Speed, John (1551/2-1629)', Oxford Dictionary of National Biography (Oxford: Oxford University Press, Sept 2004), online edn, Jan 2008 [http://www.oxforddnb.com/view/ article/26093].

Biegańska Anna 'In Search of Tolerance: Scottish Catholics and Presbyterians in Poland', Scottish Slavonic Review, XVII (Autumn 1991), 37-59.

Biegańska Anna, 'The Learned Scots in Poland: From the Mid-Sixteenth to the Close of the Eighteenth Century', Canadian Slavonic Papers, 43 (2001), 1-28.

Biegańska Anna 'Żołnierze szkoccy w dawnej Rzeczpospolitej', Studia i Materiaty do Historii Wojsk, no. 27 (1984), 81-111.

Cieszyńska Beata, 'Literackie okruchy religijnych peregrynacji Brytyjczyków w Polsce (do początków XVIII wieku)', Napis, 11 (2005), 81-96.

Cieszyńska Beata, 'Polish Religious Persecution as a Topic in British Writing in the Seventeenth and Early Eighteenth Century', Britain and Poland-Lithuania: Contact and Comparison from the Middle Ages to 1795, ed. Richard Unger, Jakub Basista (Leiden: Brill, 2008).

Clifton Robert, 'Fear of Popery', The Origins of the Civil War, ed. Conrad Russell (London: Macmillan, 1973). 
Clifton Robert, 'The Popular Fear of Catholics During the English Revolution'. Rebellion, Popular Protest and the Social Order in Early Modern England, ed. Paul Slack (Cambridge: Cambridge University Press, 1984).

Die Matrikel des päpstlichen Seminars zu Braunsberg 1578-1798, ed. Lühr Georg (Braunsberg und Ermländische Verlagsgesellschaft, 1925).

Die Schüler des Braunsberger Gymnasiums von 1694 bis 1776 nach dem Album Scholasticum Brunsbergens: in einem Anhang; Frühere Schüler der Anstalt seit 1640; Frühere Schüler der Anstalt seit 1640, ed. Lühr Georg (Braunsberg: Druck der Ermländischen Zeitungs- und Verlagsdruckerei, 1934).

Donagan Barbara ;'Codes and Conduct in the English Civil War', Past \& Present, 118 (1988), 65-95.

Fischer Thomas Alfred, The Scots in Germany: being a contribution towards the history of the Scots abroad (Edinburgh: Otto Schulze, 1902).

Encyklopedia wiedzy o Jezuitach na ziemiach Polski i Litwy 1564-1995, ed. Ludwik Grzebień (Kraków: Wydawnictwo WAM, 1996).

Flinn Michael et al., Scottish Population History from the 17th Century to the 1930s (Cambridge: Cambridge University Press, 1977).

Gibson Alex J. S., Smout Thomas Christofer, Prices, Food and Wages in Scotland 1550-1780 (Cambridge: Cambridge University Press, 1995).

Gołaszewski Zenon, Bracia polscy (Toruń: Wydawnictwo Adam Marszałek, 2005).

Hall Basil, John à Lasco 1499-1560: A Pole in Reformation England (London: Dr Williams Trust, 1971).

Hans Nicholas, 'Polish Protestants and Their Connections with England and Holland in the 17th and 18th Centuries', The Slavonic and Eastern European Review, XXXVII (1958/1959), 196-220.

Hanusiewicz-Lavallee Mirosława, 'Brytania i Sarmacja - na krańcach Europy’, Wśród krajów Pótnocy. Kultura Pierwszej Rzeczypospolitej wobec narodów germańskich, stowiańskich i naddunajskich: mapa spotkań, przestrzenie dialogu, ed. Mirosława Hanusiewicz-Lavallee (Warszawa: Wydawnictwo UW, 2015).

Huntston Williams George, The Polish Brethren: documentation of the history and thought of Unitarianism in the Polish-Lithuanian Commonwealth and in the Diaspora 1601-1685 (Missoula, Mont.: Scholars' Press, 1980).

Uczniowie - Sodalisi gimnazjum jezuitów w Brunsberdze (Braniewie) 1579-1623, eds. Marek Inglot, Ludwik Grzebień (Kraków: WSFP “Ignatianum” 1998).

Jürgens Henning P., Jan Łaski 1499-1560. Europejczyk doby reformacji (Warszawa: Semper, 2006).

Kot Stanisław, 'Bruce, William', Polski Słownik Biograficzny, vol. 3, 3-4 (Warszawa: Ossolineum, 1937).

Kowalska Halina, Działalność reformatorska Jana Łaskiego w Polsce 1556-1560 (Warszawa: Neriton, 1999).

Kowalski Waldemar, The Great Immigration: Scots in Cracow and Little Poland, circa 1500-1660 (Leiden: Brill, 2015).

Kowalski Waldemar, 'The Placement of Urbanised Scots in the Polish Crown During the Sixteenth and Seventeenth Centuries', Scottish Communities Abroad In The Early Modern Period, ed. Alexia Grosjean, Steve Murdoch (Leiden: Brill, 2005). 
Kowalski Waldemar, 'The Reasons for the Immigration of Scots to the Polish Commonwealth in the Early Modern Period as Outlined in Contemporary Opinions and Historiography' Paper presented to the Scotland and Poland: a Historical Relationship, 1500-2009 Conference, School of History, Classics and Archaeology (Edinburgh: The University of Edinburgh, October 1-2, 2009).

Kowalski Waldemar, Wielka imigracja. Szkoci w Krakowie i Ma ${ }^{3}$ opolsce w XVI-pierwszej połowie XVII wieku (Kielce: Wydawnictwo Uniwersytetu Humanistyczno-Przyrodniczego im. Jana Kochanowskiego, 2010).

Kriegseisen Wojciech, Between State and Church: Confessional Relations from Reformation to Enlightenment: Poland - Lithuania - Germany - Netherlands (Bern: Peter Lang Edition, 2016).

Love Walter D., 'Civil War in Ireland. Appearances in Three Centuries of Historical Writing', Emory University Quarterly (1966), 57-72.

Mierzwa Edward Alfred, 'Angielska relacja o Polsce z roku 1598', Annales UMCS, 17 (1962), 88-96.

Mierzwa Edward Alfred, Anglia a Polska w XVII wieku (Toruń: Wydawnictwo Adam Marszałek, 2003).

Mierzwa Edward Alfred, Anglia a Polska w pierwszej połowie XVII w. (Warszawa: Państwowe Wydawnictwo Naukowe, 1986).

Mierzwa Edward Alfred, Anglia a Polska w epoce Jana III Sobieskiego (Łódź: Wydawnictwo Łódzkie, 1988).

Milton John R., 'Locke, John (1632-1704)', Oxford Dictionary of National Biography (Oxford: Oxford University Press, Sept 2004); online edn, May 2008 [http://www.oxforddnb.com/ view/article/16885].

Murdoch Steve, Network North: Scottish Kin, Commercial and Covert Associations in Northern Europe 1603-1746 (Leiden: Brill, 2006).

Papers Relating to the Scots in Poland 1576-1593, ed. Francis Archibald Steuart (Edinburgh: Scottish Historic Society, 1915).

Piszcz Edmund, Colloquium Charitativum w Toruniu A.D. 1645: geneza iprzebieg (Toruń: Wydawnictwo Konserwatra Diecezjalnego, 1995).

Siochrú Michael O., 'Atrocity, Codes of Conduct and the Irish in the British Civil Wars 1641-1653' Past \& Present, 195 (2007), 55-86.

Rodgers Dirk Wayne, 'Á Lasco [Laski], John (1499-1560)', Oxford Dictionary of National Biography (Oxford: Oxford University Press, 2004) [http://www.oxforddnb.com/view/article/16081].

Rodgers Dirk Wayne, John à Lasco in England (New York-Washington: Peter Lang, 1994).

Royan Nicola, 'Barclay, John (1582-1621)' Oxford Dictionary of National Biography (Oxford: Oxford University Press, Sept 2004); online edn, Jan 2008 [http://www.oxforddnb.com/view/ article/1342].

Snobelen Stephen D., 'Isaac Newton, Heretic: The Strategies of a Nicodemite', British Journal for the History of Science, 32 (1999), 381-419.

Sobecki Sebastian, 'The Authorship of a Relation of the State of Polonia, 1598', The Seventeenth Century, 18, no. 2 (2003), 172-179.

Springer Michael S., 'Johannes a Lasco, a Polish and European reformer', A Companion to the Reformation in Central Europe, ed. Howard Louthan, Graeme Murdock (Leiden: Brill Publishing, 2015).

Springer Michael S., Restoring Christ's Church: John a Lasco and the Forma ac ratio (Aldershot: Ashgate, 2007). 
Taźbierski Zdzisław, 'Związki Polski z Anglią od schyłku XIV do połowy XVII wieku', Studium zdziejów polityki dynastycznej (Olsztyn: Wyższa Szkoła Pedagogiczna, 1994).

Teslar Józef Andrzej, 'Polskie wydawnictwa ariańskie w bibliotekach angielskich' Rocznik Polskiego Towarzystwa Naukowego na Obczyźnie, IX (1958-69), 46-86.

The Oxford Companion to English Literature, ed. Margaret Drabble, $5^{\text {th }}$ edition (Oxford: Oxford University Press, 1985).

Tomkowicz Stanisław 'Przyczynek do historii Szkotów w Krakowie i w Polsce', Rocznik Krakowski 2 (1899), 151-174.

Uczniowie - Sodalisi gimnazjum jezuitów w Brunsberdze (Braniewie) 1579-1623, eds. Marek Inglot, Ludwik Grzebień (Kraków: WSFP “Ignatianum” 1998).

Westfall Richard S., 'Newton, Sir Isaac (1642-1727)', Oxford Dictionary of National Biography (Oxford: Oxford University Press, Sept 2004); online edn, Jan 2009 [http://www.oxforddnb. $\mathrm{com} /$ view/article/20059].

Williams Huntston George, The Polish Brethren: Documentation of the History and Thought of Unitarianism in the Polish-Lithuanian Commonwealth and in the Diaspora 1601-1685 (Missoula, Mont.: Scholars Press, 1980).

Wolff Larry, Inventing Eastern Europe: The Map of Civilization on the Mind of the Enlightenment (Stanford, Calif.: Stanford University Press, 1994).

Young John T., 'Durie, John (1596-1680)', Oxford Dictionary of National Biography (Oxford: Oxford University Press, Sept 2004); online edn, Jan 2008 [http://www.oxforddnb.com/view/ article/8323].

Zins Henryk, Polska w oczach Anglików XIV-XVI wieku (Warszawa: Państwowy Instytut Wydawniczy, 1974). 